\author{
Magdalena Jarczok-Guzy \\ University of Economics in Katowice \\ e-mail: magdalena.guzy@ue.katowice.pl \\ ORCID: 0000-0001-9373-1264
}

\title{
CHANGES IN INCOME TAXES IN POLAND IN THE OPINION OF SMALL AND MEDIUM ENTERPRISES
}

\section{ZMIANY W PODATKACH DOCHODOWYCH W POLSCE W OPINII MALYCH I ŚREDNICH PRZEDSIECIORSTW}

DOI: $10.15611 /$ pn.2019.5.05

JEL Classification: G38, H25, H21

\begin{abstract}
Summary: This article is a presentation of primary research conducted within the research potential of the Department of Public Finance of the University of Economics in Katowice entitled "Instruments of the state's fiscal policy and the development of small and medium-sized enterprises." The research goal of the work is to present the opinions of entrepreneurs on the most important post-shift changes introduced in Poland in 2017-2018. Fifty medium-sized enterprises in Poland with different activity profiles and territorial coverage comprised the research object. The methods of statistical analysis and deduction were used. As a result of the analysis, it turned out that the entrepreneurs' enthusiasm for reforms was high. Entrepreneurs positively evaluated the new privileges and preferences, most of them also took advantage of the available privileges. The work also discusses the consecutively introduced changes in a concise manner.
\end{abstract}

Keywords: income tax, legal changes, one-off depreciation write-off.

Streszczenie: Niniejszy artykuł stanowi analizę badań pierwotnych przeprowadzonych w ramach potencjału badawczego Katedry Finansów Publicznych Uniwersytetu Ekonomicznego w Katowicach pt. „Instrumenty polityki fiskalnej państwa a rozwój małych i średnich przedsiębiorstw”. Celem badawczym pracy była prezentacja opinii przedsiębiorców na temat najistotniejszych zmian podatkowych wprowadzonych w Polsce w latach 2017-2018. Obiekt badań stanowiło 50 średnich przedsiębiorstw w Polsce o różnych profilach działalności i zasięgu terytorialnym. Zastosowano metodę analizy statystycznej oraz dedukcji. W wyniku przeprowadzonej analizy okazało się, że entuzjazm przedsiębiorców w odniesieniu do reform był duży. Przedsiębiorcy pozytywnie ocenili nowe przywileje i preferencje. Większość przedsiębiorców skorzystała również z dostępnych przywilejów. W pracy omówiono też w sposób zwięzły kolejno wprowadzone zmiany.

Słowa kluczowe: podatek dochodowy, zmiany prawne, jednorazowy odpis amortyzacyjny. 


\section{Introduction}

A stable tax environment is an important element of any business activity. An entrepreneur who is well-informed about the duties and rights related to the fulfillment of a tax obligation may run his/her business more calmly and plan his/her investment decisions. From the point of view of small and medium-sized enterprises, the principle of tax certainty and stability is very important. Large enterprises deal with the new tax regulations perfectly by employing qualified staff and creating legal and financial departments. It is the most difficult thing for small entrepreneurs to navigate within the tax law. It should be noted here that in recent years (2017 and 2018), the new tax preferences and privileges abounded, addressed mainly to small and medium enterprises. This especially concerned small taxpayers whose sales revenues did not exceed 1.2 million euros.

These changes have led to starting research among medium-sized enterprises. They are used to assess the introduced changes and to perceive the currently conducted tax policy. Undoubtedly, similar research will be necessary in the next few years, because in 2019 the new changes have already been introduced. Therefore the aim of this work is to present the opinions of entrepreneurs and their behavior towards the selected privileges. Sampling was determined by the above research team.

\section{Selected changes in taxes in 2017-2018}

A further environment includes all the elements that create the conditions in which enterprises operate, regardless of their internal (systemic) properties. They create couplings affecting the enterprise and all the other enterprises, and they take the form of legal norms, environmental standards, financial regulations, and taxes. In this way, they create conditions for the operation of enterprises in the environment [Ciupek, Famulska 2013, p. 18]. The individual changes listed below were selected for the survey:

1. a preferential CIT rate of $15 \%$ for small taxpayers

2. the rise on the limit of a low-value fixed asset to PLN 10,000

3. the introduction of a one-off write-down of a factory-new asset

4. R\&D tax reliefs

5. activities in the tax capital group

These individual changes and preferences are briefly described below.

\subsection{The preferential tax rate of CIT $15 \%$}

The tax act refers to the solutions adopted in the Tax Code by indicating the category of taxpayers. The Tax Ordinance defines a taxpayer as a natural person, a legal person, an organizational unit without legal personality. These entities become taxpayers 
when they are subject to tax obligations under the tax laws [Gomułowicz, Mączyński 2016, p. 149]. Since January 1, 2017, the so-called small taxpayer and a taxpayer who starts a business can take advantage of a reduced $15 \%$ corporate income tax rates. The decrease of the tax rate from $19 \%$ to $15 \%$ is the result of the entry into force of the changes introduced by the Act of the $5^{\text {th }}$ September 2016 amending the Act on personal income tax and the Act on corporate income tax. The amendment limited the privilege of a lower rate for taxpayers starting a business activity and taxpayers who have the status of the so-called small CIT taxpayer. According to the CIT Act, a small taxpayer is an entity whose value of sales revenue (along with the amount of due tax on goods and services) in the previous tax year does not exceed an amount expressed in zlotys, which corresponds to the equivalent of 1.2 million Euros [Act of 15 February...]. According to this research, 50\% of enterprises used this privilege.

\subsection{The rise on the limit of a low-value fixed asset to PLN 10,000}

Since the beginning of 2018, the limit of the value of fixed assets or intangible assets allowing a one-off recognition of expenses for the purchase of such assets or the value to the tax-deductible costs has increased from the existing PLN 3,500 to PLN 10,000. The so-called a large amendment to the Income Tax Act introduces the appropriate changes both in the PIT Act and in the CIT Act. The new limit applies to assets accepted for use after December 31,2017. The new privilege is treated by Article 22a par. 1 and Article 22b par. 1 of the PIT Act, and respectively Article 16a and $16 \mathrm{~b}$ of the CIT Act [Act of 27 October $2017 \ldots$ ]; $43 \%$ of the entrepreneurs used this method in their business.

\subsection{The introduction of a one-off depreciation write-off of a brand new fixed asset}

A one-off depreciation write-off is expected for brand-new fixed assets classified to groups 3 to 6 and 8 of the Classification of Fixed Assets. This impairment loss relates to non-current assets with an initial value of at least PLN 10,000. Such possibilities are provided by Article 22 par. 1s of the Personal Income Tax Act. A new factory fixed asset is such equipment (a machine, device) that has never been used before by the entrepreneur who bought it or by any other taxpayer. A one-off write-off of such fixed assets is limited to PLN 100,000 [Act of 27 October 2017...]; 28\% rated this privilege positively.

\section{4. $R \& D$ tax reliefs}

In accordance with the introduced changes, the limits of write-offs have increased, the costs of contracts of specified work and contracts of mandate are deducted, entities operating on the basis of permission in special economic zones can make use of R\&D 
tax reliefs under certain conditions. Particularly beneficial changes concern research and development centres, where higher tax write-offs have replaced the previously existing innovation fund. Research and Development Centres deduct $150 \%$ of costs, while large, small and medium-sized enterprises account for $100 \%$. Starting from 2018, employees' wages and contributions are being deducted in the part in which the time allocated for the realization of R\&D is included in the employee's overall working time, the acquisition of materials and raw materials, the due use of scientific and research equipment, expert opinions, advisory services, depreciation write-offs from fixed assets used in the conducted research and development, the costs of obtaining a patent for an invention, protection right for a utility model, and rights from the registration of an industrial design [www.pwc.pl]. The Corporate Income Tax Act for R\&D is considered as a creative activity involving research or development work, undertaken in a systematic manner to increase knowledge resources and the use of knowledge resources to create new applications [Act of 15 February $1992 \ldots] ; 46 \%$ of the respondents said that they used these rules.

\subsection{Activities in the tax capital group}

According to Article 1a of the Corporate Income Tax Act, a tax capital group is a taxpayer if the following conditions are cumulatively fulfilled, a tax capital group may be only formed by limited liability companies or joint-stock companies established on the territory of the Republic of Poland, if:

a) average share capital, determined in the manner mentioned in par. $2 b$, falling on each of these companies, is not lower than PLN 500,000,

b) one of the companies, hereinafter referred to as "the parent company", has a direct $75 \%$ share in the share capital or the part of the share capital of other companies, hereinafter referred to as "subsidiaries", which under the commercialization and privatization regulations was acquired by employees, farmers or fishermen, not granted free or on preferential terms, or which is not a Treasury property reserve for the purpose of re-privatization,

c) subsidiaries do not hold shares in the share capital of other companies forming this group,

d) in these companies there are no arrears in tax payments that constitute the state budget income.

The parent company and its subsidiaries include, in the form of a notarial deed, a contract to produce for a period of at least three fiscal years.

For each tax year, the tax capital group must achieve the share of income in revenues determined in accordance with Article 7a par.1, in the amount of at least $2 \%$ [Act of 15 February $1992 \ldots$ ]; $10 \%$ of the respondents have benefited from this form of taxation. 


\section{Research methodology and discussion}

Fifty medium-sized enterprises from all over Poland were selected for the research sample. A telephone interview was conducted with each entrepreneur with the use of a questionnaire. The graphs below show the structure of the test sample according to the characteristics of the certificate. Data are given in percentages.

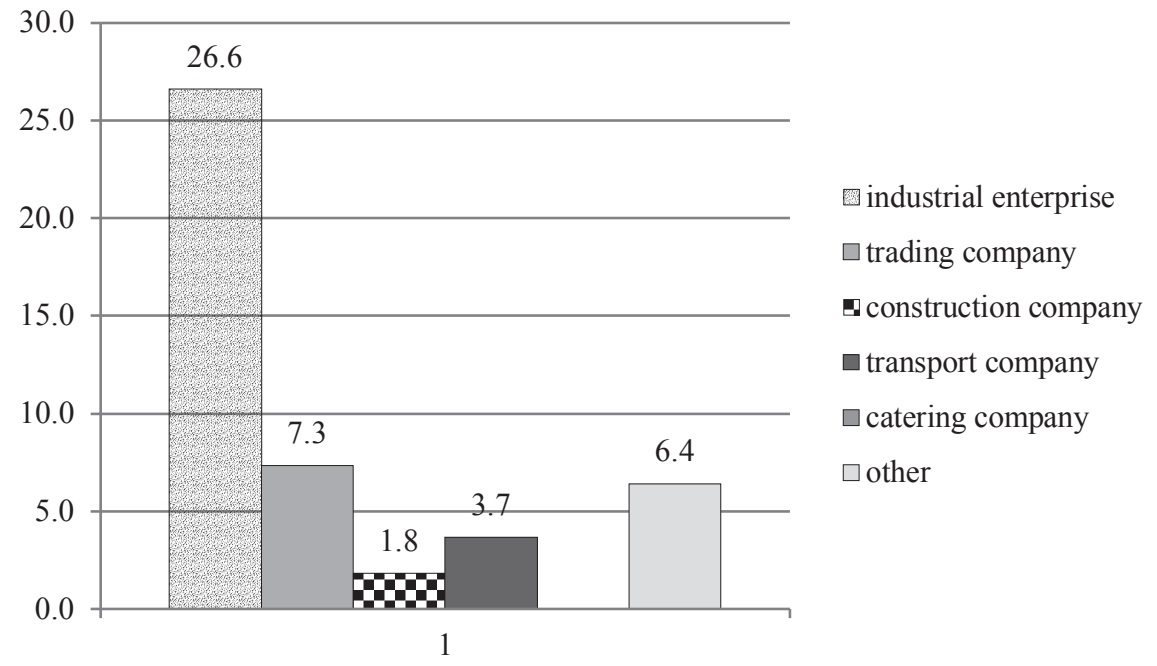

Fig. 1. Profile of business activity

Source: own elaboration on the basis of primary research.

Most of the respondents are industrial companies and limited liability companies (26.6\%). They provide their business services for more than 10 years $(90 \%)$, Most of the companies have a national owner (98\%), while many of them operate on regional $(38 \%)$ and international markets $(38 \%)$.

As a result of the conducted survey, an analysis of the obtained results was made.

The first questions concerned the tax changes in the form of the CIT rate reduced to $15 \%$, the increase of the limit of a low-value fixed asset to PLN 10,000 and the introduction of a one-off write-off of a factory-new asset. This assessment is presented in Table 1. It is clearly visible that all the preferences presented to the respondents were positively evaluated. 


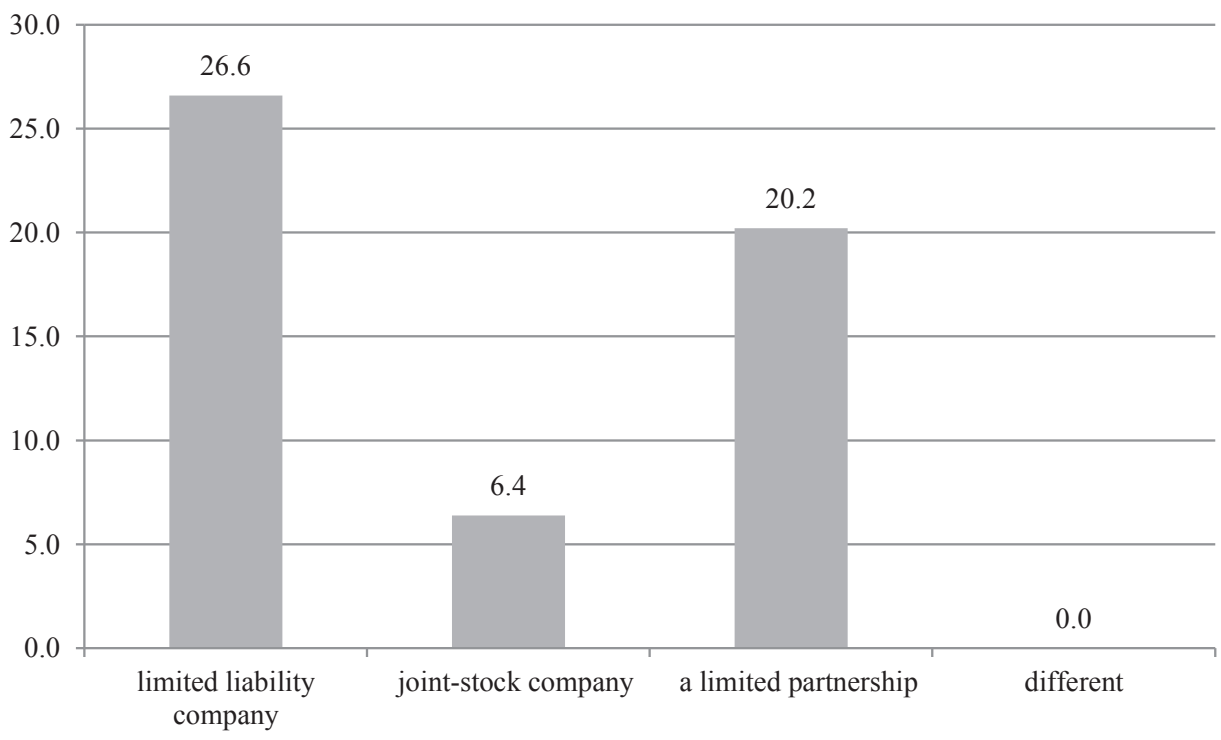

Fig. 2. Organizational and legal form

Source: own elaboration on the basis of primary research.

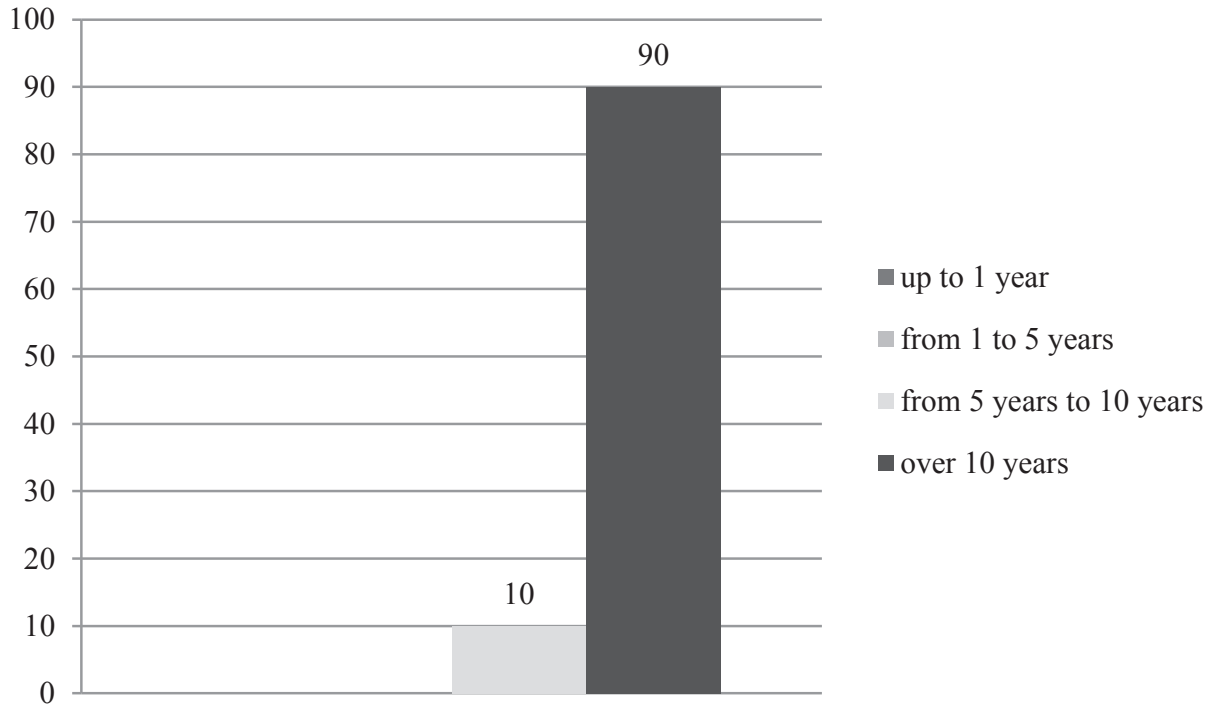

Fig. 3. The period of business activity

Source: own elaboration on the basis of primary research. 


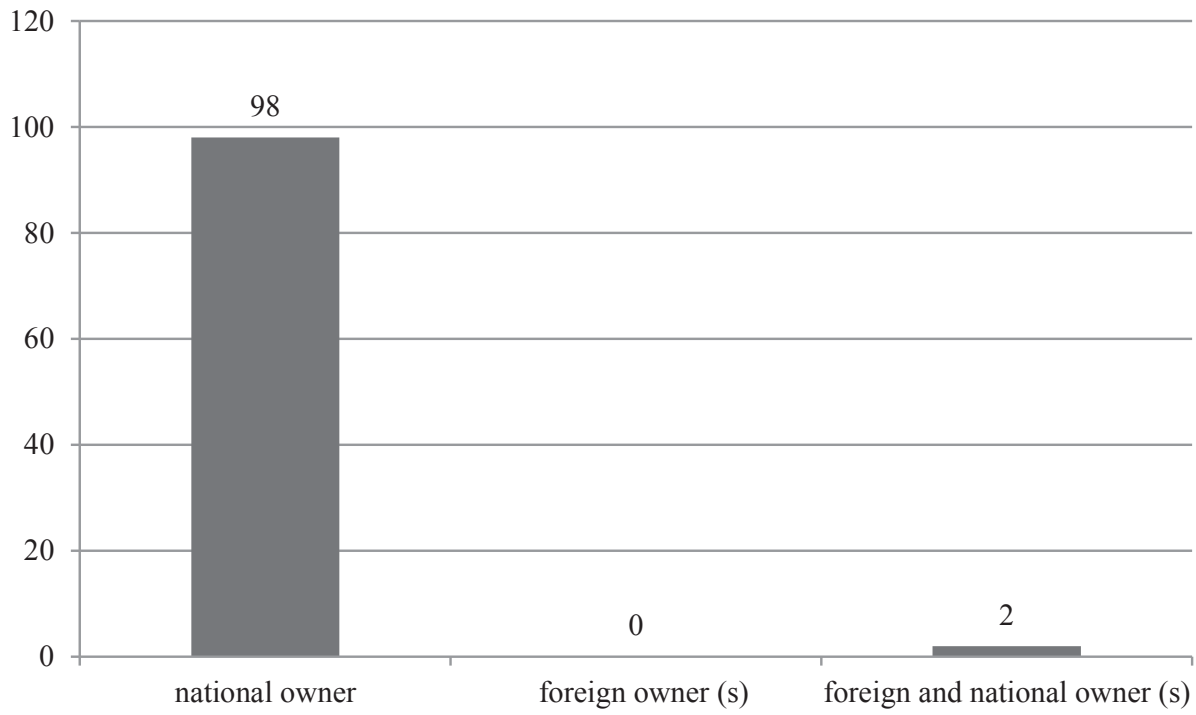

Fig. 4. The origin of capital

Source: own elaboration on the basis of primary research.

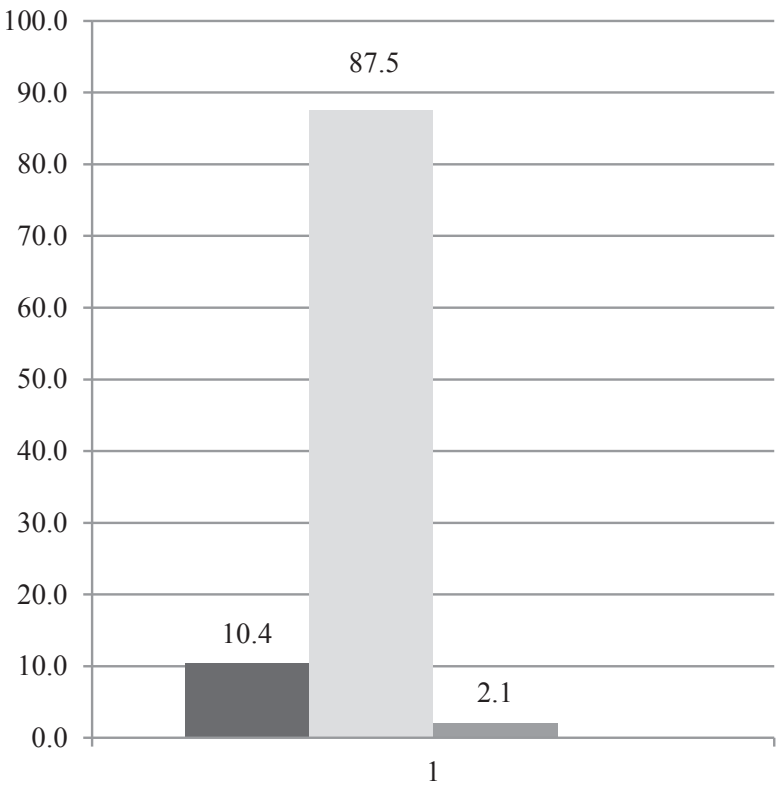

- the annual turnover does not exceed EUR 2 million or the balance sheet total does not exceed PLN 2 million

the annual turnover does not exceed EUR 10 million or the balance sheet total does not exceed PLN 10 million

- the annual turnover does not exceed EUR 50 million or the balance sheet total does not exceed PLN 43 million

- the annual turnover exceeds EUR 50 million or the balance sheet total exceeds PLN 43 million

Fig. 5. Annual turnover and balance sheet total

Source: own elaboration on the basis of primary research. 


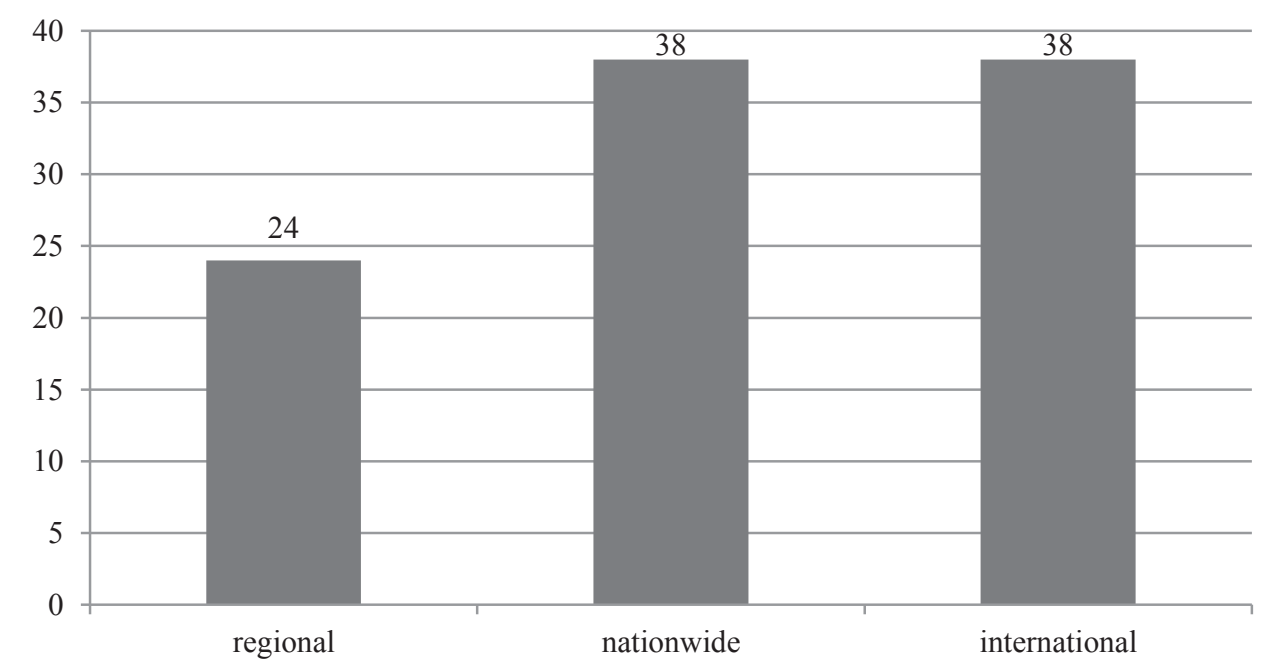

Fig. 6. Territorial range

Source: own elaboration on the basis of primary research.

Table 1. Evaluation of introduced tax changes

\begin{tabular}{|l|c|c|c|c|}
\hline \multicolumn{1}{|c|}{ Answer } & Positively & $\begin{array}{c}\text { Rather } \\
\text { positively }\end{array}$ & $\begin{array}{c}\text { Rather } \\
\text { negatively }\end{array}$ & Negatively \\
\hline Introduction of a tax rate for CIT-15\% & $30 \%$ & $64 \%$ & $4 \%$ & $2 \%$ \\
\hline $\begin{array}{l}\text { Rise on the limit of a low-value fixed } \\
\text { asset to PLN 10,000 }\end{array}$ & $28 \%$ & $66 \%$ & $4 \%$ & $2 \%$ \\
\hline $\begin{array}{l}\text { Introduction of a one-off write-off for } \\
\text { a brand new fixed asset }\end{array}$ & $0 \%$ & $65 \%$ & $2 \%$ & $2 \%$ \\
\hline
\end{tabular}

Source: own elaboration on the basis of primary research.

Then the respondents were asked whether they benefited from individual tax preferences. The results are presented in Table 2. The respondents' answers to this question were almost fifty-fifty, which could indicate some concerns of the respondents prior to using the new privileges.

Table 2. Using the tax preferences

\begin{tabular}{|l|c|c|}
\hline \multicolumn{1}{|c|}{ Answer } & Used & Not used \\
\hline Introduction of a tax rate for CIT - 15\% & $50 \%$ & $50 \%$ \\
\hline Introduction of a one-off write-off for a brand new fixed asset & $42.9 \%$ & $57.1 \%$ \\
\hline
\end{tabular}

Source: own elaboration on the basis of primary research. 
Next the respondents were asked to assess the impact of individual tax changes on the development of their enterprises. Table 3 clearly shows that these changes have affected enterprises in a positive way.

Table 3. The impact of tax preferences on enterprise's development

\begin{tabular}{|l|c|c|c|c|}
\hline \multicolumn{1}{|c|}{ Answer } & Positively & $\begin{array}{c}\text { Rather } \\
\text { positively }\end{array}$ & $\begin{array}{c}\text { Rather } \\
\text { negatively }\end{array}$ & Negatively \\
\hline Introduction of a tax rate for CIT - 15\% & $56 \%$ & $44 \%$ & $0 \%$ & $0 \%$ \\
\hline $\begin{array}{l}\text { Introduction of a one-off write-off for a brand } \\
\text { new fixed asset }\end{array}$ & $33.3 \%$ & $66.7 \%$ & $0 \%$ & $0 \%$ \\
\hline
\end{tabular}

Source: own elaboration on the basis of primary research.

The use of further preferences is illustrated in Table 4. The respondents are not afraid to use the preferences. The exception is the activity in the tax capital group the vast majority of respondents do not use this preference. The very establishment of a tax capital group is a difficult procedure that involves requirements which must be met to create such a company. The complex requirements may discourage entrepreneurs.

Table 4. Using tax preferences

\begin{tabular}{|l|c|c|}
\hline \multicolumn{1}{|c|}{ Answer } & Used & Not used \\
\hline R\&D Reliefs & $46 \%$ & $54 \%$ \\
\hline Preferential tax rate & $60 \%$ & $40 \%$ \\
\hline Membership in a tax capital group & $10 \%$ & $90 \%$ \\
\hline
\end{tabular}

Source: own elaboration on the basis of primary research.

Table 5. Evaluation of introduced tax changes

\begin{tabular}{|l|c|c|c|c|}
\hline \multicolumn{1}{|c|}{ Answer } & Positively & $\begin{array}{c}\text { Rather } \\
\text { positively }\end{array}$ & $\begin{array}{c}\text { Rather } \\
\text { negatively }\end{array}$ & Negatively \\
\hline R\&D Relief & $16 \%$ & $74 \%$ & $10 \%$ & $0 \%$ \\
\hline Preferential CIT tax rate & $24 \%$ & $70 \%$ & $6 \%$ & $0 \%$ \\
\hline Membership in a tax capital group & $6 \%$ & $80 \%$ & $16 \%$ & $0 \%$ \\
\hline
\end{tabular}

Source: own elaboration on the basis of primary research.

The assessment of other tax preferences is presented in Table 5. In this case, the respondents were also very positive about the new tax preferences. 


\section{Conclusion}

This article presents a survey on the entrepreneurs' opinion and their behavior towards changes in taxes. The research has proved that the introduction of tax privileges in 2017 and 2018 has been very positively received by entrepreneurs. In most cases they are not afraid to use them. An exception is the participation in a tax capital group that entrepreneurs are reluctant to use. It should be noted here that these are only the subjective perceptions of the business community and the opinions of the selected sample. On their basis, one can only cautiously conclude how the tax changes are perceived by other entrepreneurs. For the sake of completeness of the impact of individual changes on the finances of enterprises, detailed financial analyzes in each of the surveyed entities would be desirable. However, the purpose of this analysis was to assess these fiscal policy instruments and the objective of the work has been achieved.

\section{Bibliography}

Act of 15 February 1992 on corporate income tax, Dz. U. 1992, No. 21 item 86 with later amendments. Act of 27 October 2017 amending the act on personal income tax, the act on corporate income tax and the act on flat-rate income tax on certain revenues earned by natural persons, Dz. U. pos. 2175.

Ciupek B., Famulska T., 2013, Strategie podatkowe przedsiębiorstw, Wydawnictwo Uniwersytetu Ekonomicznego w Katowicach, Katowice.

Gomułowicz. A. Mączyński D., 2016, Podatki i prawo podatkowe, Wolters Kluwer, Warszawa. https://www.pwc.pl/alert-ulga-b-r-cbr-pwc.pdf (11.03.2019). 